University of Nebraska - Lincoln

DigitalCommons@University of Nebraska - Lincoln

Agronomy \& Horticulture -- Faculty Publications

Agronomy and Horticulture Department

10-1946

\title{
Reduction of Un-Grazed Mixed Prairie to Short Grass as a Result of Drought and Dust
}

\author{
F. W. Albertson \\ Fort Hays, Kansas State College \\ J. E. Weaver \\ University of Nebraska-Lincoln
}

Follow this and additional works at: https://digitalcommons.unl.edu/agronomyfacpub

Part of the Plant Sciences Commons

Albertson, F. W. and Weaver, J. E., "Reduction of Un-Grazed Mixed Prairie to Short Grass as a Result of Drought and Dust" (1946). Agronomy \& Horticulture -- Faculty Publications. 496.

https://digitalcommons.unl.edu/agronomyfacpub/496

This Article is brought to you for free and open access by the Agronomy and Horticulture Department at DigitalCommons@University of Nebraska - Lincoln. It has been accepted for inclusion in Agronomy \& Horticulture -Faculty Publications by an authorized administrator of DigitalCommons@University of Nebraska - Lincoln. 
REDUCTION OF UNGRAZED MIXED PRAIRIE TO SHORT GRASS AS A RESULT OF DROUGHT AND DUST

F. W. Albertson

Fort Hays Kansas State College

AND

J. E. WEAVER

Dniversity of Nebraska 
TABLE OF CONTENTS

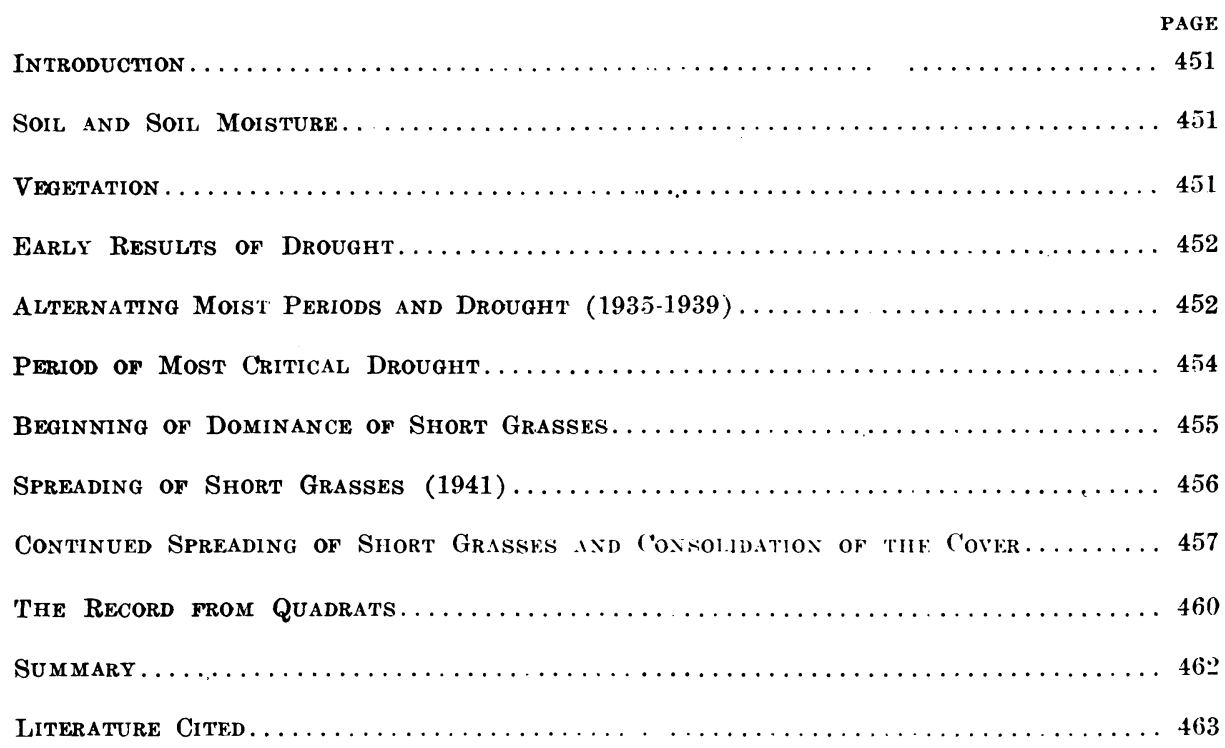




\section{REDUCTION OF UNGRAZED MIXED PRAIRIE TO SHORT GRASS AS A RESULT OF DROLGHT AND DUST}

\section{INTRODUCTION}

Many marked changes have occurred over vast areas of native grassland in central North America as a result of the recent desiccation and wide-spread distribution of dust. The gradual replacement of true prairie by mixed prairie over an area 100 to 150 miles in width in central Kansas, eastern Nebraska, and eastern South Dakota has been described (Weaver, 1943). Great changes in both true and mixed prairie as a result of long periods of drought have heen reeorded by Albertson and Weaver (1942) and Weaver and Albertson $(1943,1944)$. The present study of the gradual reduction of a typical area of mixed prairie to short grass without the impact of grazing has extended over a period of many years. It is illustrative of a very widely spread phenomenon that necurred mostly during the past decade.

Certain grassland areas lying south of Phillipsburg in north-central Kansas were selected by the second author in 1920 as trpically representative of mixed-prairie vegetation. These were studied in regard to the plant cover and the envirommental relations over a period of three vears (Weaver, 1924). They have been re-examined almost every year since. The prairie lying 8 miles south of Phillipsburg is 130 rods long from north to south and 55 rods wide, and about 45 acres in area. It was one of the several permanent grassland stations maintained in mixed prairie by the authors during the many years of drought and the subsequent period of recovery.

\section{SOIL AND SOIL MOISTURE}

The station is characteristic of the gently rolling topography of the gencral area. The fertile soil is a mellow, dark-brown, very fine sandy-loam of the Holdrege series. At a depth of 12 to 15 inches it is slightly lighter in color and contains enough clay to be quite sticky, although when wet it is dark in color to a depth of 2 fret. Below this level it is light rellow and shows throughout its loess origin. It is not acid at any depth. The mellow subsoil is very deep. The hygroseopic eoefficients are about 11 pereent in the first font, 12.5 in the second and third, and 10 to 11 pereent to 5 feet in depth. The orranic matter in the soil areraged 4.56 percent and the nitrogen 0.206 pereent. A mechanical analysis is given in Table 1 .

The moan amnual precipitation is $\mathbf{2 3 . 2}$ inches but in certain years following heary rainfall the soil has been well moistened to a depth of 8 feet. In other years the deeper subsoil had no water available for plant growth and drought in the upper
TABLE 1. Mcchanical analyses of soils from Phillipsburg, Kansas.

\begin{tabular}{|c|c|c|c|c|c|c|c|c|}
\hline $\begin{array}{l}\text { Depth, } \\
\text { feet }\end{array}$ & $\begin{array}{l}\text { Coarse } \\
\text { gravel }\end{array}$ & $\begin{array}{c}\text { Fine } \\
\text { gravel }\end{array}$ & $\begin{array}{l}\text { Coarse } \\
\text { sand }\end{array}$ & $\begin{array}{l}\text { Medi- } \\
\text { um } \\
\text { sand }\end{array}$ & $\begin{array}{l}\text { Fine } \\
\text { sand }\end{array}$ & $\begin{array}{l}\text { Very } \\
\text { fine } \\
\text { sand }\end{array}$ & Silt & Clay \\
\hline $0.0-0.5$ & 0.0 & 0.0 & 0.3 & 0.2 & 1.2 & 43.5 & 35.8 & 19.0 \\
\hline $0.5-1.0 \ldots$ & 0.0 & 0.0 & 0.0 & 0.2 & 0.5 & 44.4 & 32.8 & 22.1 \\
\hline $1-2 \quad \ldots$ & 0.0 & 0.0 & 0.0 & 0.2 & 0.3 & 39.7 & 34.0 & 25.8 \\
\hline $2-3 \quad \ldots$ & 0.0 & 0.0 & 0.0 & 0.3 & 0.6 & 41.2 & 31.9 & 26.0 \\
\hline $3-4 \quad \ldots$ & 0.0 & 0.0 & 0.0 & 0.1 & 0.2 & 37.5 & 31.4 & 30.8 \\
\hline
\end{tabular}

soil was of common occurrence. During three years of approximately normal precipitation (1920 to 1922 inclusive) soil moisture was ascertained (Clements and Weaver, 1924). In 1920, July and early August were periods of soil drought and, at times, of actual deficiency of available water. During 1921, water arailable for growth was almost exhausted one week in July and two in August; no water was available to a depth of 4 feet late in August. The next year, a period when little or no water was available in the soil occurred in June, and this condition was nearly constant from the middle of July until late in autumn. Hence, the plants of this prairie are often subjected to moderate drought even during years of normal precipitation.

\section{VEGETATION}

The regetation was typical mixed prairie, the mid grasses alternating with or forming a laver above the shorter ones. Little bluestem (Andropogon scoparius), side-oats grama (Bouteloua curtipendula) and western wheat grass (Agropyron smithii) were the chief mid grasses. But tall grasses occurred abundantly on the moist slopes, in ravines, and on level land where there was little runoff. Most abundant among these were big bluestem (Andropogon furcatus), Indian grass (Sorghastrum nutans), and nodding wild rye (Elymus canadensis). The short grasses consisted chiefly of blue grama (Bouteloua gracilis) with buffalo grass (Buchloe dactyloides) usually more or less intermixed. They occurred on the drier slopes in pure stands but were found more or less thrnughout, except under dense patches of hig bluestem and other taller grasses where light was greatly reduced. The forbs were those typical of mixed prairie: the absence of certain less xeric specie: common eastward and the presence in abundance of more westerly species indicated a drier climate than that of true prairie. Among the latter were Astragalus mollissimus, Oxytropis lambertii, Malvastrum coccincum. Opuntia fragilis, and Sideranthus spinulosus. Further description here seems 
unnecessary, since the behavior of the various components of the vegetation will be discussed. In this prairie, half-square meter samples of soil containing the underground parts of pure stands of big bluestem, western wheat grass, blue grama, and buffalo grass were obtained by Shively and Weaver in 1.936 in their study of the amount of underground plant materials in different grassland climates (1939).

\section{EARLY RESLLTS OF DROUGHT}

A careful survey late in June, 1934, after a single year of drought and dusting revealed that much damage had been done. The basal cover was far less than normal. There were many places where the grass had been covered with 0.5 to 2.5 inches of dust. This had been compacted by rains and the grasses were dead or dying. The deeper the dust burial the thinner was the stand of big bluestem. There were great losses of blue grama and especially of buffalo grass in the alternes of short grass. There were many clumps of half-dead sand dropseed (Sporobolus cryptandrus). No living little bluestem, needle grass (Stipa comata), June grass (Koeleria cristata), or low-growing panic grasses were found. Antennaria campestris, Viola papilionacea, Astragalus crassicarpus and various other forbs of the understory were likewise killed.

The whole prairie had been covered with dust. Over half of it the dust was at least 0.25 inch deep and much vegetation over several acres of the north end had been covered to a depth of 0.5 to 2.5 inches or even more. Here, especially, great losses had occurred. In the deeply dusted ${ }^{1}$ part all native grasses had been killed or at least only a few bunches per square meter remained (Fig. 1). Frequently the lowest joints of Opuntia humifusa were entirely buried and only a few green tips of big bluestem were seen. While the following weeds were scattered in patches or as individuals throughout the whole prairie, here they occurred in great abundance. The chief species were lamb's quarters (Chenopodium album and $C$. leptophyllum), peppergrass (Lepidium densiflorum), Russian thistle (Salsola pestifer), foxtail (Setaria viridis), sunflower (Helianthus annuus), pigweeds (several species of Amaranthus), and cocklebur (Xanthium commune). The general level of pigweeds was about 9 inches, but sometimes patches twice this height occurred. Thus, the whole prairie had a peculiarly irregular or ragged appearance; over half its area it could not be distinguished from a very weedy pasture.

Deeply dusted and extremely weedy places also occurred at the south end where big bluestem had lost more than half of its territory by dusting and drought. A new growth of some deeply buried big bluestem had reached a height of 2 to 3 inches but the plants were dying from lack of water, since the compacted dust furnished an efficient barrier to penetration of rain. While many dead bunches of vari-

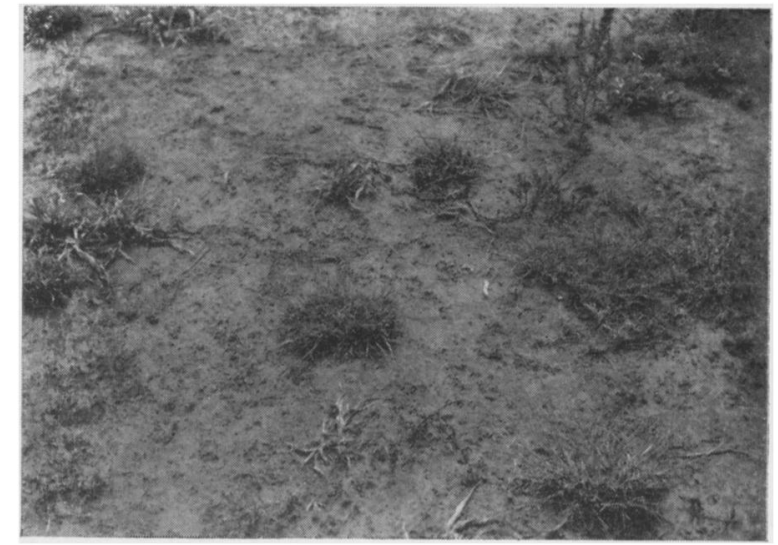

FIG. 1. Typical view in drought-stricken and dustcovered portion of prairie. Only a few relict bunches or patches of short grass remain. Russian thistle (Salsola pestifer) and witchgrass (Panicum capillare) are beginning the subsere.

ous grasses occurred, the best evidence of destruction was the open cover and much bared ground. The death of little bluestem seemed to be total, but loss of big bluestem was about 35 percent.

In this scene of destruction spring rains had resulted in an excellent growth of much remaining big bluestem over considerable areas. Blue grama and buffalo grass were flowering abundantly. In the opened cover the stolons of buffalo grass were the best developed in many years. These grasses were thriving even where partially buried by dust. Many of the taller and deeply rooted forbs remained. Chief among these were Kuhnia glutinosa, Solidago glaberrima, and Psoralea tenuiflora. But even these had been greatly reduced in numbers. Malvastrum coccineum was not affected; Gaura coccinea was common. Ambrosia psilostachya had greatly thickened its stands in ravines; Aster multiflorus and Solidago mollis had become a brush-like growth where vegetation on lower slopes had been greatly thinned or disappeared. Other species present included Sideranthus spinulosus, Opuntia humifusa. Lygodesmia juncea, Allionia linearis, Allium nuttallii, and Anemone caroliniana. These have been pointed out previously by the writers as being among the most drought resistant forbs of mixed prairie (Weaver and Albertson, 1940).

\section{ALTERNATING MOIST PERIODS AND DROUGHT (1935-1939)}

This five-year interval will long be remembered as one of intense drought alternating with periods of rainfall sufficient to revive the vegetation and even promote vigorous growth. But decreases or loss of certain species alwavs equaled or exceeded the gains made by others. The net result was a gradual decrease in tall and most mid grasses and less xeric forbs, offset by an increase in short grasses and sideoats grama. A transient populatien of annual 
weeds, although often greatly dwarfed, was characteristic.

By June of 1937 the short grass portion of the cover had been reduced to about 25 percent of its former abundance. This reduction was not uniform but ranged from no loss in some favored places to 80 percent destruction in others (Fig. 2). Death of big bluestem also averaged about 25 percent but varied from 0 to 50 percent. Only dead bunches and no living shoots of little bluestem were found. Over the deeply dusted portions 80 percent or more of the cover of grasses had disappeared.

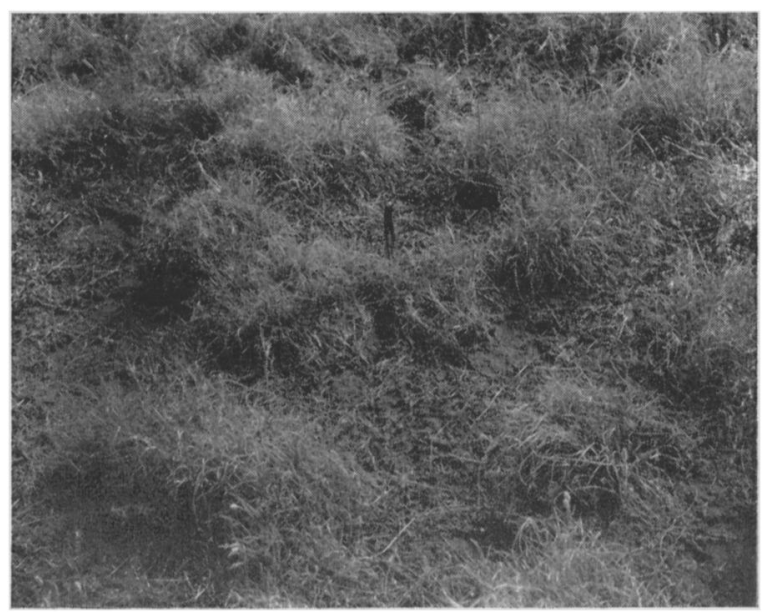

Fia. 2. Blue grama (Bouteloua gracilis) making an excellent growth during a favorable season in the drought years. Note that more than half of the soil surface is bare.

The short grasses were thriving due to early summer rains and lack of the competing mid-grass layer. The tufts and patches of buffalo grass, which were less abundant than those of blue grama, were enlarging rapidly by the spreading of long runners over the dead crowns of the taller grasses. Blue grama increased its hold by filling its crown area with stems and by extending the periphery by means of new tillers. New tufts were established from seedlings. The foliage cover of these survivors spread far more widely than normally. In patches of buffalo grass the foliage cover was usually 80 to 100 percent, due in part to an enormous production of stolons. Many bare interspaces were occupied by annuals such as species of Chamaesyce. Panicum capillare, and Eragrostis cilianensis.

By the autumn of 1937 the short grasscs ranked first in abundance with blue grama forming by far the most of this type of vegetation (Fig. 3). Sideoats grama, a species which increased greatly during certain years with moist springs, held second rank (Fig. 4). Big bluestem was reduced to third place. Blue grama and side-oats grama had produced a good seed crop but buffalo grass and big bluestem failed in this important function.

Examination in late May, 1939, revealed that sideoats grama had increased enormously. Many of

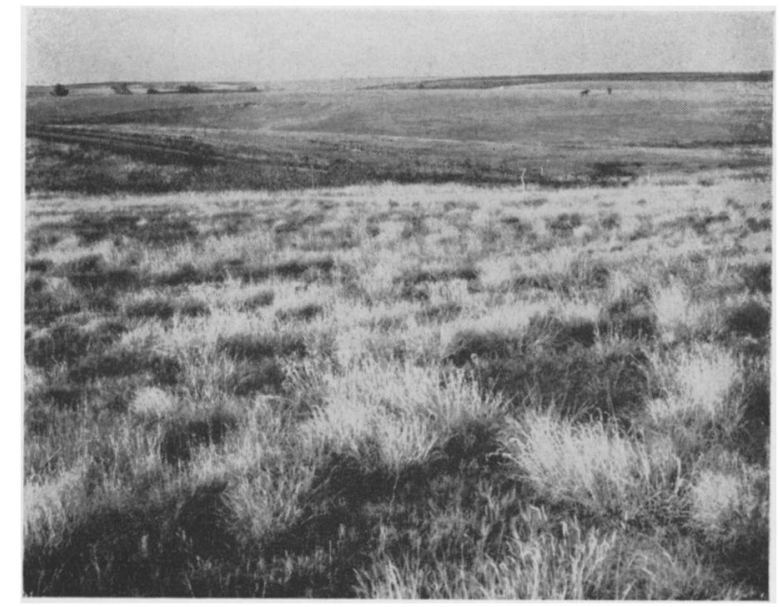

Fig. 3. Photo Aug. 26, 1937, showing replacement of bluestem grasses (Andropogon furcatus and $A$. scoparius) over a north-east slope in the Phillipsburg prairie. 'The prairie in the background had long since been reduced by grazing to a buffalo grass disclimax.

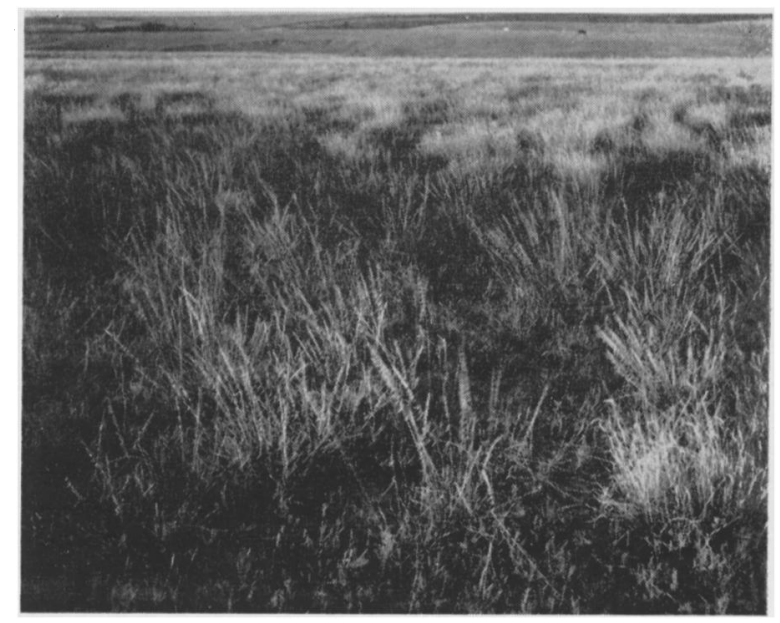

FIG. 4. Beginning of the side-oats grama (Bouteloua curtipendula) type (foreground) in soil almost bared by several years of drought. Aug. 26, 1937.

the bunches were 8 to 14 inches in basal diameter. This grass ranked as the most important dominant (Fig. 5). In other areas bunches of relict blue grama were pronounced. It also had increased very greatly and ranked second in importance. When peppergrass and plantain (Plantago purshii and $\boldsymbol{P}$. spinulosa) were removed the wide spacing of the bunches was elearly revealed. The prairic had not been mowed the preceding autumn, which was the usual practice, and the old forage crop remained. The spreading of buffalo grass during the drought period of 5 or 6 years now gave it third place in abundance. So great was the desiccation that only small amounts of big bluestem survived in areas where it had been abundant. Some of the space had been occupied by sand dropseed, which was the fourth grass in importance. Most of the bare 


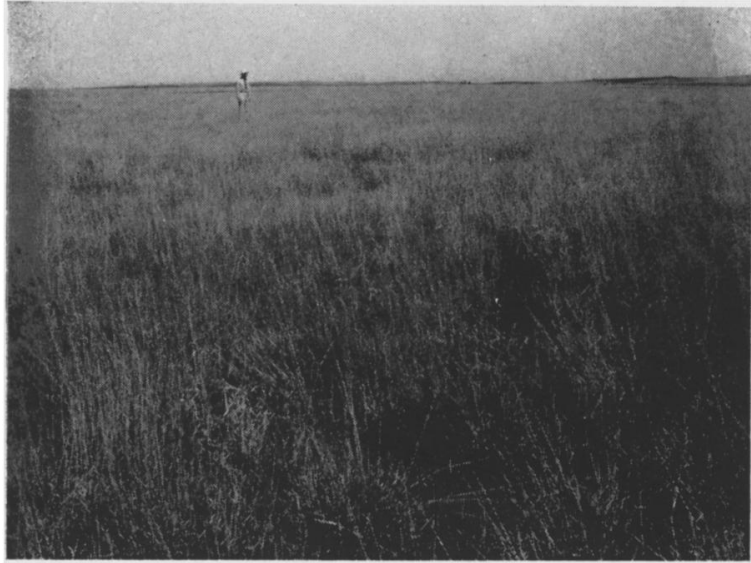

Fig. 5. Dense, almost continuous stand of side-oats grama on level upland in the Phillipsburg prairie. May 25,1939 . The flower stalks are those of the preceding year.

ground everywhere was covered with weeds. Tall dropseed (Sporobolus asper) and nodding wild rye occurred, the first rather abundantly in patches (Fig. 6).

A second examination late in August confirmed these conditions. The widely spaced bunches of sideoats grama composed an open basal cover of about 10 percent; the foliage cover was very much greater. There was as yet no understory of short grasses. These occurred in scattered patches of various sizes, but often of only a few square feet. Such patches very abundant, and islands of buffalo grass about ten square feet in area were very common. Stolons of this grass had often grown directly through bunches of blue grama and sand dropseed. Since there was no mowing, the mat of stems and leaves of buffalo grass, 4 to 6 inches thick, was piled about the bases of the mid grasses and stolons extended through the bunches. Because of the reduced water supply, even the greatly thinned stands of big bluestem could barely survive.

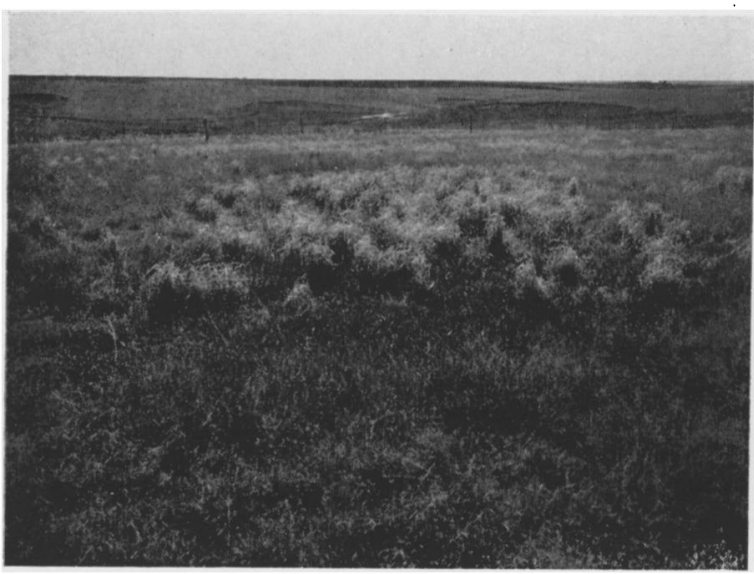

Fig. 6. Increase of tall dropseed (Sporobolus asper) after the cover of climax grasses was broken by drought. May 25, 1939.
In the small to large open spaces, abundant everywhere, seedlings of buffalo grass of the previous year had developed into many new tufts. This was also true of blue grama and side-oats grama. There was considerable tumblegrass (Schedonnardus paniculatus). Only a few bunches of wiregrass (Aristida purpurea) remained alive. All of the forbs previously mentioned as relicts still remained.

Most of the bared soil was occupied by annuals. These were thickest where there was some degree of shading, that is in the smaller bared places. But many irregular, large bare areas 6 to 10 inches in length were also more or less completely occupied by weeds. By far the most abundant were little barley (Hordeum pusillum) and peppergrass, but stickseed (Lappula occidentalis) was plentiful. The rough pennyroyal (Hedeoma hispida) was common, and plantain was abundant in the short grasses. Size of these annuals varied from season to season. During the driest years, as 1939, they seldom exceeded 2 to 3 inches in height and those of later germination barely protruded through the soil surface when overtaken by drought. They often dried prematurely and produced little or no seed since not infrequently they were sustained only by soil moisture supplied by melting snow.

\section{PERIOD OF MOST CRITICAL DROUGHT}

Following the cumulative effects of dry years, the autumn and winter of 1939-40 were extremely dry, and the year 1940 was one of severe drought. The prairie had been mowed about 3 inches high the preceding autumn. In May, examination of typical areas where side-oats grama dominated showed that the basal cover was not more than 8 to 10 percent, and sometimes much less (Fig. 7). The bare soil between the bunches was covered with hosts of annual weeds, since there was enough soil moisture in early spring to permit seed germination. The weeds were spaced so closely that not more than 10 percent of the soil was bare. They were chiefly stickseed and peppergrass but wild mustard (Sophia multifida) and

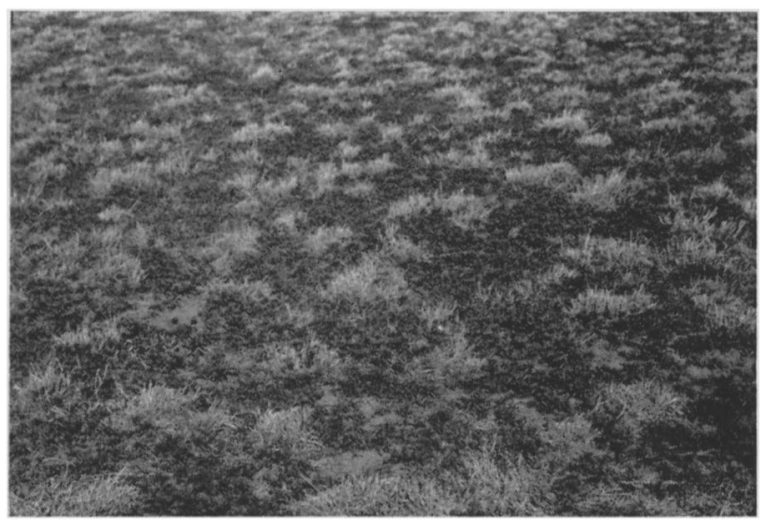

Fig. 7. Photo in stand of side-oats grama mowed the preceding fall. White patches are the bases of the bunches; the soil between them was clothed with a host of annual weeds. May 25, 1940. 
plantain were abundant locally. In areas where snow had accumulated and in melting moistened the soil, little barley grew thickly. Russian thistle and pigweeds also occurred abundantly in places, and common sunflower in the most disturbed parts. The sod of blue grama, originally a cover of 80 to 95 percent, was broken up into a pattern of isolated bunches with a basal area rarely exceeding 20 percent.

\section{BEGINNING OF DOMINANCE OF SHORT GRASSES}

Conditions at an examination early in June, 1940, were almost tragic. Drought the preceding autumn was so drastic that only a little vegetation was left alive for spring growth. There was a dense cover of low, weedy plants such as peppergrass, stickseed, and plantain. But the relict short grasses had made only a little growth and were becoming dormant. Side-oats grama was practically all dead but there were scattered shoots of sand dropseed growing in a few of the widely spaced crowns. The occurrence of tufts and small bunches of blue grama almost everywhere showed clearly the great spread of this species, just as its thickening in places formerly occupied showed its ability to grow during drought when most other grasses succumbed (cf. Weaver and Darland, 1944). The most spectacular fact, however, was the wide spreading of buffalo grass. From wind-blown and animal-carried seed supplied by earlier, well established plants and from adjacent pastures, it had developed countless new bunches or small tufts. Indeed, it seemed almost as abundant and as widely distributed as blue grama. On the drier slopes where it had previously occurred in this mixed prairie, it had spread widely taking over the soil left bare by the dead mid grasses. This had also taken place over considerable portions of the adjacent, dusted, level areas. Here the replacement of mixed prairie by a short grass disclimax was well advanced. Elsewhere the process was under way. It seemed that short grasses might dominate the whole prairie.

By the middle of June the drought was so severe that blue grama was becoming dormant. The new growth of leaves had rolled when only 3 to 5 inches long and many had lost their green color. Many large bunches had dead centers with only a peripheral fringe of new growth. Leaves of buffalo grass had twisted spirally and were only half green. The new stolons were also drying. Side-oats grama was practically all dead and had made no new growth. Bunches of sand dropseed were still alive, but new shoots were few and the leaves were rolled tightly. The few scattered bunches of wiregrass were in a similar condition. Western wheat grass, which grew only in old haystack bottoms, along fences, and on protected but deeply dusted slopes, was much wilted. Even the annual weeds were very much dwarfed and wilted, except in places where snow had accumulated and in melting supplied extra soil moisture.

Late in August of 1940, this grassland no longer had the appearance of a mixed prairie, but that of a depleted short grass disclimax. This change in appearance was due to the loss of nearly all of the taller grasses and the wide distribution of short grasses. Side-oats grama, so abundant the preceding year, had suffered an almost total loss. The dead bases occurred almost throughout. Only in a few places were bunches found that still showed life in the crown. Nodding wild rye and Indian grass, found locally and sparingly the preceding year, had succumbed. Western wheat grass was entirely dried; the invading sand dropseed, which formerly grew in a few patches, was dead. Nor was any trace of living little bluestem or big bluestem to be seen. In fact, the short grasses alone had made a fair growth and although developing slowly they were reclothing the soil (Fig. 8).

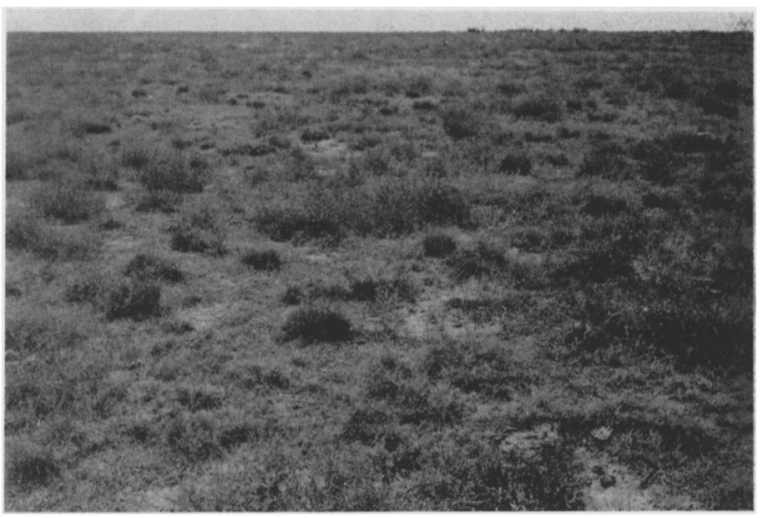

Fig. 8. General view on August 25, 1940, showing dead bunches of side-oats grama and spreading of blue grama and buffalo grass (detail in foreground). Much of the bare soil is obscured by dried annual weeds.

The drab or gray color in August was due largely to the dense population of dried stickseed and the lighter gray to dried plants of little barley intermixed with those of peppergrass. All of these weeds were only 4 to 8 inches tall, little barley having dried when the spikes were only half exerted from the protecting leaf sheath. Even the taller weeds as Russian thistle and lamb's quarters were only about a foot in height, so severe was the drought. This dull background was lightened by the bright straw-colored and dormant buffalo grass. The cover of native plants, which consisted almost entirely of the two short grasses, did not occupy more than 5 to 6 percent of the soil. Patches of bare ground occurred everywhere, varying from a few square inches to a few square yards in area.

Native forbs had been greatly decimated both in species and numbers. Solidago mollis was the only one that was fairly widely distributed; it formed conspicuous societies in some ravines. Its xerophytism was shown by profuse blossoming in this graveyard of dead plants.

A complete list of the perennial plants observed included only 11 species. These were Malvastrum coccineum, Opuntia humifusa, Lygodesmia juncea, 
Kuhnia glutinosa. Sideranthus spinulosus, Gaura coccinea, Allionia lincaris, Anemone caroliniana, Solidago mollis, the very deeply rooted Psoralea tenuiflora, and Vinonia baldwini, the last being confined to ravines. All were much dwarfed; nearly all including eactus showed wilting; many had not blossomed.

\section{SPREADING OF SHORT GRASSES (1941)}

Heavy rainfall followed the dry vears just described. In April precipitation totaled 5.6 inches. That of May was 2.5 , but June had a total precipitation of 8.7 inches. Thus, the soil which lacked available water for plant growth almost continuously in 1940 was now wet or at least moist to j feet in depth (Fig. 9).

Environmental conditions were conducive to growth but, except for the short grasses which had steadily increased during the preceding years of drought, there was little vegetation left to profit from the changed environment. In many places no perennial grasses could be found even in June. This was especially true in areas previously occupied by side-oats grama and sand dropseed. Nearly all of the bunches of these grasses failed to revive; in others it was not uncommon to find only a few living tillers protruding from the edges of the clumps. But where short grasses had grown, most of them had survived. They were handicapped, however, by the excellent growth of little barley 12 to 20 inches tall which occurred in thick stands locally. After ripening it had lodged at a height of 3 to 6 inches, thus producing dense shade. Even in the best stands of buffalo grass this annual grew plentifully and the short grass was much shaded. In thin stands of buffalo grass it was so abundant that it was very harmful in reducing the light in addition to absorbing large amounts of water. The seed had germinated in fall and the plants grew rapidly early in spring, overtopping all of the other vegetation. The growth of the short grasses was greatly suppressed. The tillers of blue grama were much attenuated and light green in color as was also the foliage on the stolons of buffalo grass. The yield of the little barley alone averaged a ton per acre.

Seedlings of perennial grasses were rare. Nearly all had germinated following showers during the dry years. Here, as elsewhere over the broad expanse of the mixed prairie, a good year for the production of seed followed by another year favorable for the establishment of seedlings was required for revegetation by native grasses, except buffalo grass (Weaver and Mueller, 1942). But the annuals, little barley, peppergrass, and stickseed were scattered, unusually thickly, over the otherwise bare soil.

By midsummer the stolons of buffalo grass had spread widely and the foliage was unusually well developed. Blue grama and small amounts of surviving side-oats grama and sand dropseed had produced flower stalks. Many open places bare of native

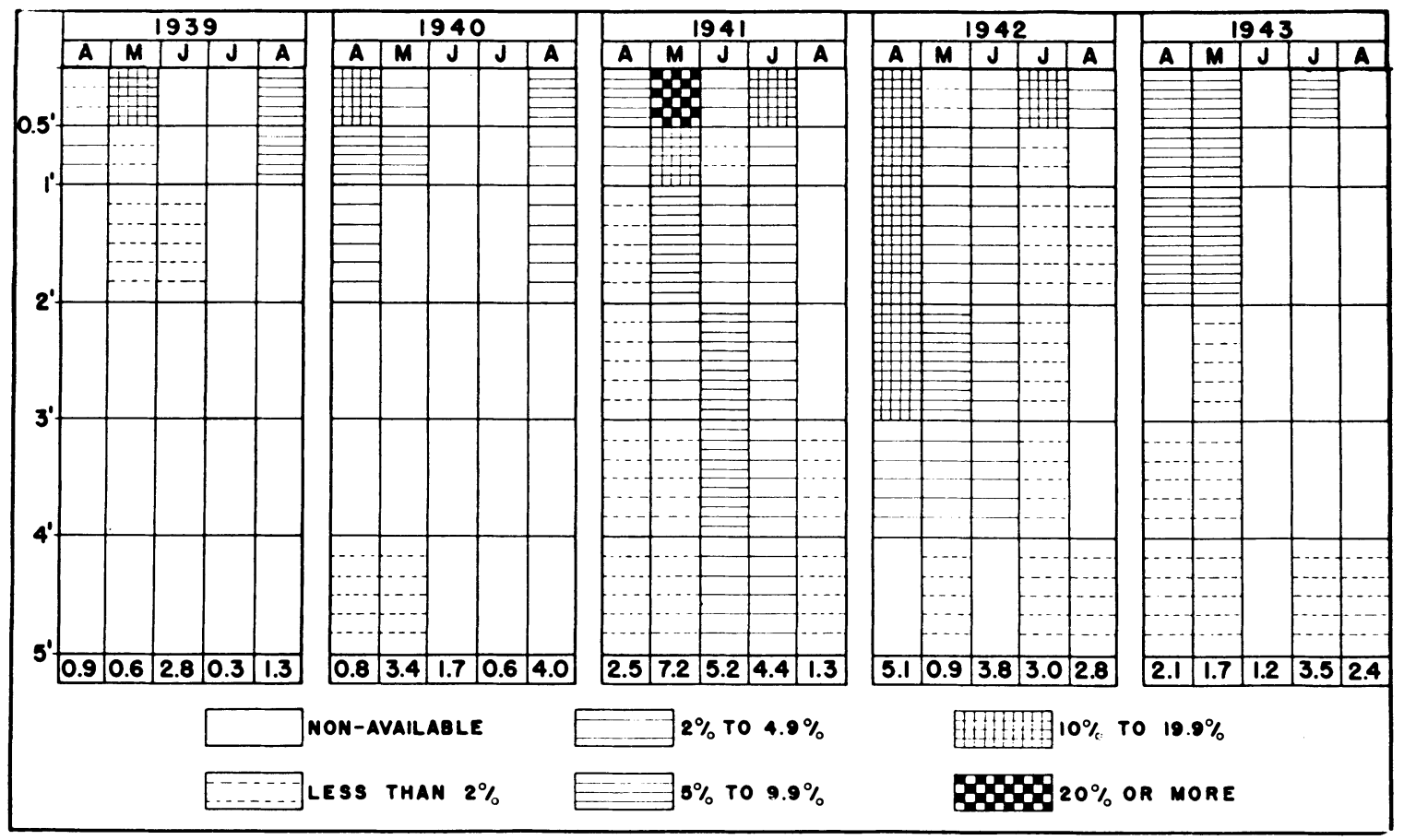

Fig. 9. Available soil moisture to a depth of 5 feet each month of the growing season in the prairie at Phillipsburg, Kansas, in 1939 to 1943, inclusive. Letters at the head of the columns indicate the months, and numbers at the foot show the current monthly rainfall. Data for 1944 (not shown here) are very similar to those in 1943. 
vegetation were clothed with witchgrass (Panicum capillare), Russian thistles, and pigweeds. The witchgrass was of great size, often plants were 3 feet in height and width. It formed dense, large patches. Growth continued into September. For the first time in many years a few flower stalks had been produced by relict big bluestem. The short grasses had consolidated their gains and almost completely covered many areas locally.

In some ravines western wheat grass had replaced all other native grasses, but this condition was local. It also had complete occupation of other small areas where drifts of dust had been deposited by the wind. It grew in pure stands and was spreading from areas disturbed by stacking hay.

After prolonged study, it was estimated that the soil over 30 percent of the entire prairie was without a long-lived cover. Of the remainder, about 78 percent was occupied, usually by open stands of short grass, but over a third of this, short grasses were dense enough to make the invasion of mid grasses difficult. Side-oats grama, widely scattered and in a drought-weakened condition occupied 12 percent, tall dropseed about 8 , and western wheat grass the remaining 2 percent.

The prairie had the aspect of a short grass disclimax except for the open alternes of side-oats grama and bared places with widely scattered bunches of tall dropseed. Perennial forbs were not conspicuous. But the tall plants of common sunflower, lamb's quarters, and other weeds indicated the open cover or bared soil elsewhere.

The following lists of grasses or grass-like plants, forbs, and ruderals constituted the vegetation. The grasses are arranged in order of their abundance, the last three being rare.

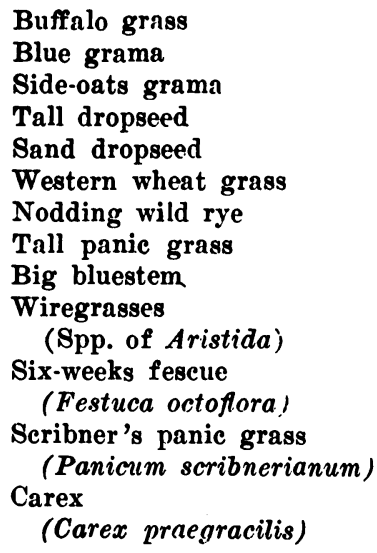

All of the forbs previously listed for 1940 persisted but they were greatly reduced in number. They were all that remained of a predrought list of more than 50 species. Annual weeds composed a long list as follows:

Amaranthus graecizans

Amaranthus retroflexus

Bromus tectorum

Chamaesyce spp.
Chenopodiumi album

Eragrostis cilianensis

Helianthus annuus

Hordeum pusillum

Lappula occidentalis

Lepidium densiflorum

Leptilon canadense

Mollugo verticillata

Panicum capillare

Plantago purshii

Plantago spinulosa

Polygonum ramosissimum

Salsola pestifer

Sophia multifida

\section{CONTINUED SPREADING OF SHORT GRASSES AND CONSOLIDATION OF THE COVER}

Late in August, 1942, the prairie was green and in a thriving condition. One could scarcely recognize it as the old prairie with the broken-down cover (Fig. 10). The short-grass type presented a wonderful appearance with an average basal cover of 50 percent and a foliage cover varying between 80 and 100 percent. About 60 percent was blue grama and nearly all of the remainder buffalo grass. The old alternes and scattered patches of short grass had merged over many acres to form a continuous expanse of this type. Blue grama had an abundance of flower stalks which portended a good crop of seed. Buffalo grass had already produced seed but relied mostly on vegetative propagation. The carpet of short grasses was 6 to 8 inches thick. Throughout the entire prairie, large pure alternes of short grass were found. The trend nearly everywhere was toward short grasses. Closing of the mat had excluded nearly all of the weeds both annual and perennial.

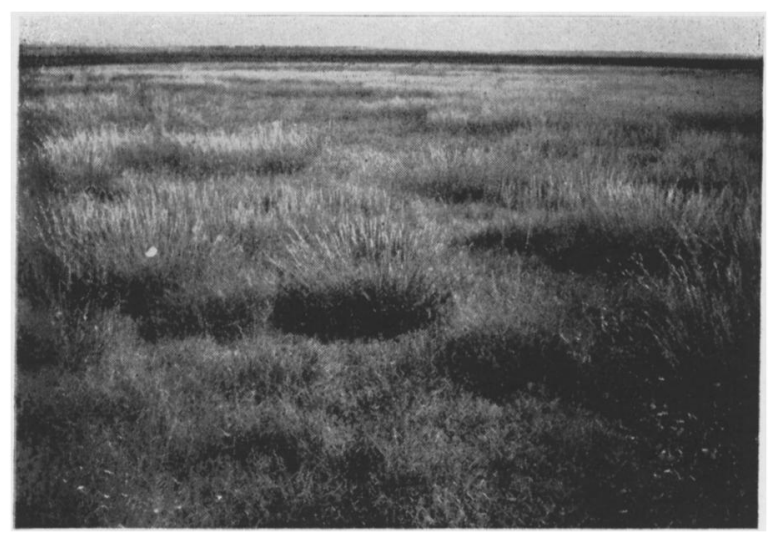

Fig. 10. View in the prairie on August 21, 1942. Note the thriving bunches of side-oats grama and the carpet of short grasses with blue grama in blossom.

A second, smaller type was dominated by side-oats grama. It was being invaded along many lines of contact by buffalo grass and blue grama. This type occurred as alternes, both large and small, in the widely spread short-grass cover. The mid-grass 
cover formed by side-oats grama was often quite open. The bunches were rather regularly widely spaced but of large size. Often witchgrass formed conspicuous stands between them; the purplish panicles, which were densely aggregated, reached a height of 1.5 to 2 feet. In only a small portion did the foliage cover of side-oats grama alone completely conceal the soil; nearly always there was abundant room for invasion.

A small part of the prairie, probably only 4 to 5 percent, was still dominated by weeds, and a few small spots by grasses other than the three great dominants. Small amounts of tall dropseed were found; often the plants were widely spaced. Certain older stands had been nearly replaced by the invasion of buffalo grass. Sand dropseed formed a few, dense, nearly pure stands in dust-covered soil and some was scattered thinly in the side-oats grama, but its importance was not great. One ravine was mostly filled with a pure stand of western wheat grass, the former cover of tall panic grass having been reduced to a narrow patch only 15 feet long. Up the ravine, above the wheat grass, the largest area of big bluestem was found. It was about 10 feet wide and 45 feet long, tapering thereafter into a very narrow belt down to the wheat grass. Elsewhere, it occurred only rarely and as isolated bunches usually a square foot or less in area. But it had flower stalks 4 to 6 feet tall, and seedling bluestems were found about the parent plants. It was a pitiful "last stand" of this grass which was at one time one of the most abundant dominants. In other former strongholds it had completely failed. Little bluestem fared even worse. It was found very sparingly in one limited area on a north slope. Only a trace of wiregrass was seen. Fxcept for a trace of nodding wild rye, tall panic grass, and a very little big bluestem, the whole deeply dusted northern portion of the prairie had now been occupied by western wheat grass.

A deep gray mulch of the dried and lodged stems of little barley was very common. Panicum scribnerianum and Eragrostis spectabilis showed their return in some places. The wider the spacing of the perennial grasses, the more weeds found room for growth. In places tumblegrass occurred, and prostrate spurges spread widely over the thick mulch at a height of 3 to 4 inches. Despite the carpet of little barley, seedlings of blue grama and tumblegrass were found commonly, and those of side-oats grama were plentiful. In fact, plants in all stages of development were observed as a result of growth during the wetter years. In some recently severely dusted areas, weeds were few and the seedling crop of grass, especially side-oats grama, was much larger. Buffalo grass showed vigorous but recent invasion in the periphery of many stands of this grass. Here too, seedlings of blue grama were common.

Transitions between small weedy areas and those with short grass or side-oats grama were common but not extensive. Here, as in the weedy patches, the perennial grasses had suffered the greatest losses by drought or dust burial. The relict old bunches of blue grama were noticeably large; some measured 12 to 18 inches in basal diameter and the top spread was fully 3 feet.

Ambrosia psilostachya, whose rhizomes endured the drought, was the best indicator of bare soil or soil with only a few relict bunches of blue grama or buffalo grass. It occurred in streaks or small patches. Although large isolated plants of Helianthus annuus and Gaura parviflora occurred, the prairie was not weedy and in general it was far beyond the ruderal stage. Because of the excellent year for growth, all species flourished.

As to forbs, they were few to rare. There were no societies, except of Solidago mollis in one ravine. Fven it had previously lost greatly in both numbers and stature.

In July, 1943, the accumulated debris under the short grasses was rather regularly 4 to 5 inches deep and sometimes 8 inches (Fig. 11). The new foliage of buffalo grass was 9 inches tall and that of blue grama 12 inches. Stolons of buffalo grass often extended over. this carpet 7 or 8 inches above the surface of the soil. Growth of these grasses was dense and the foliage cover usually 100 percent. The preceding vear's flower stalks of blue grama were sometimes 22 inches tall, so favorable had been the water relations. The former bare spaces in the short grass cover were now filled by young plants of blue grama or by the runners of buffalo grass which sometimes spread 11 inches from the base of the tufts.

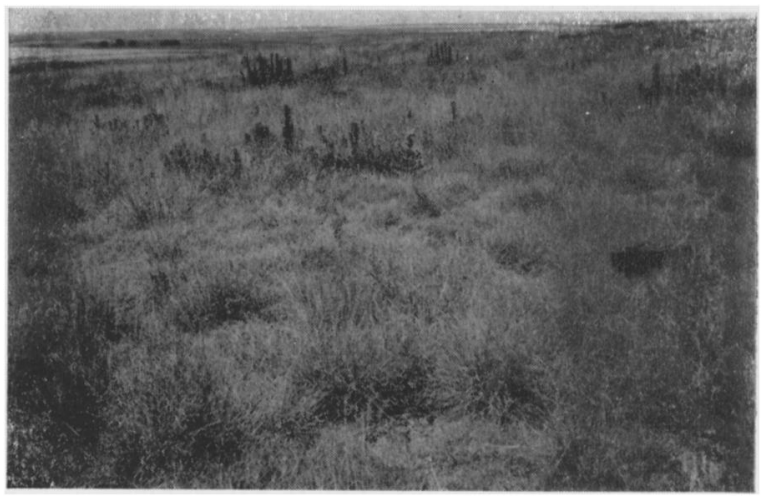

Fig. 11. View in short grass type on July 7, 1943. Note large isolated bunches of blve grama which are closely surrounded by mats of buffalo grass.

Little barley was almost absent from the short grass. Many large bunches of both blue grama and sideoats grama had died, apparently smothered by the debris. But this excellent forage did not cover the whole prairie. Where there were still interspaces, many remarkably well developed annuals occupied the soil (Figs. 12 and 13).

Large bunches of side-oats grama were scattered more or less throughout. Those in the short grass were beginning to be invaded by buffalo grass but elsewhere this grass in many places formed practically pure stands several rods wide. To a limited 


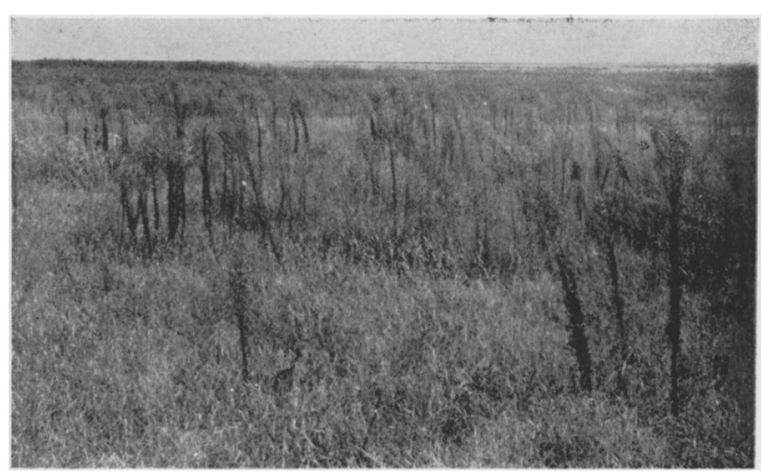

Fia. 12. Horseweed (Leptilon canadense) growing in small bare spaces where the mat of short grasses is still open (Aug. 27, 1943).

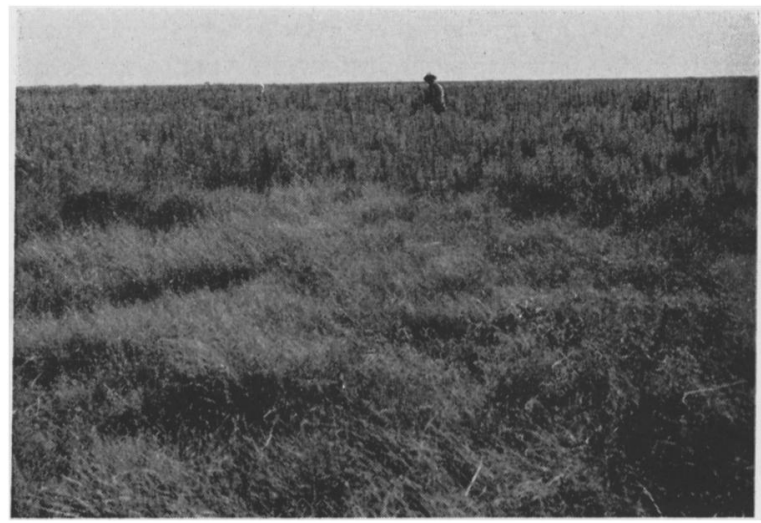

Fig. 13. Excellent development of pure short grass in foreground and weeds, mostly horseweed, in background. July 7, 1943.

extent, western wheat grass had spread to form an upper layer over the short grasses. Large, isolated, circular patches of bufialo grass alternated in the most disturbed places with wheat grass or with ruder. als, mostly horseweed. Because of the occurrence of many bare places and the unusually rank growth of various annual weeds, as common sunflower and horseweed, in them, the whole prairie had a weedy aspect. The fewer the weeds the denser was the cover of grasses. Certain grasses, such as nodding wild rye, purple lovegrass (Eragrostis spectabilis), and wiregrass were found, as well as considerable sand dropseed in the bare places. There were only a few scattered bunches of big bluestem. Forbs were few but the number of species had increased.

By August of 1944, the short grasses had extended their area greatly and in most places consolidated it into an almost continuous cover. Of this buffalo grass formed by far the larger part. Any relict sand dropseed was closely invaded and the bunches often reduced to 1 or 2 stems. Even bunches 8 inches in diameter were threaded through with stolons. Bunches of side-oats grama were suffering a similar fate. Only the centers of large and numerous patches of this grama scattered in the short grass area were free from the invading buffalo grass. This grass had now closed in completely around the bunches of blue grama and was beginning to reduce its height growth and to prevent vigorous peripheral tillering. Although there were still many patches of sunflower and witchgrass, buffalo grass was not greatly retarded in its invasion.

Some relict grasses, though few in numbers, as big and little bluestem and tall panic grass, were thriving in the most mesic places. Solidago mollis and Ambrosia psilostachya were very vigorous and locally abundant. Western wheat grass continued to spread rapidly, and relict bunches of big bluestem on the level upland, where it had been dormant for several years, put forth flower stalks. Side-oats grama was by far the most abundant of the taller grasses.

Viewed as a whole, bluestems and other predrought mixed-prairie grasses had probably reached their lowest ebb. Several tall and mid grasses in ravines had been almost replaced by western wheat grass. The abundance of sunflowers and witchgrass was somewhat misleading. The tall growth of the composite tended to overemphasize the amount of bare

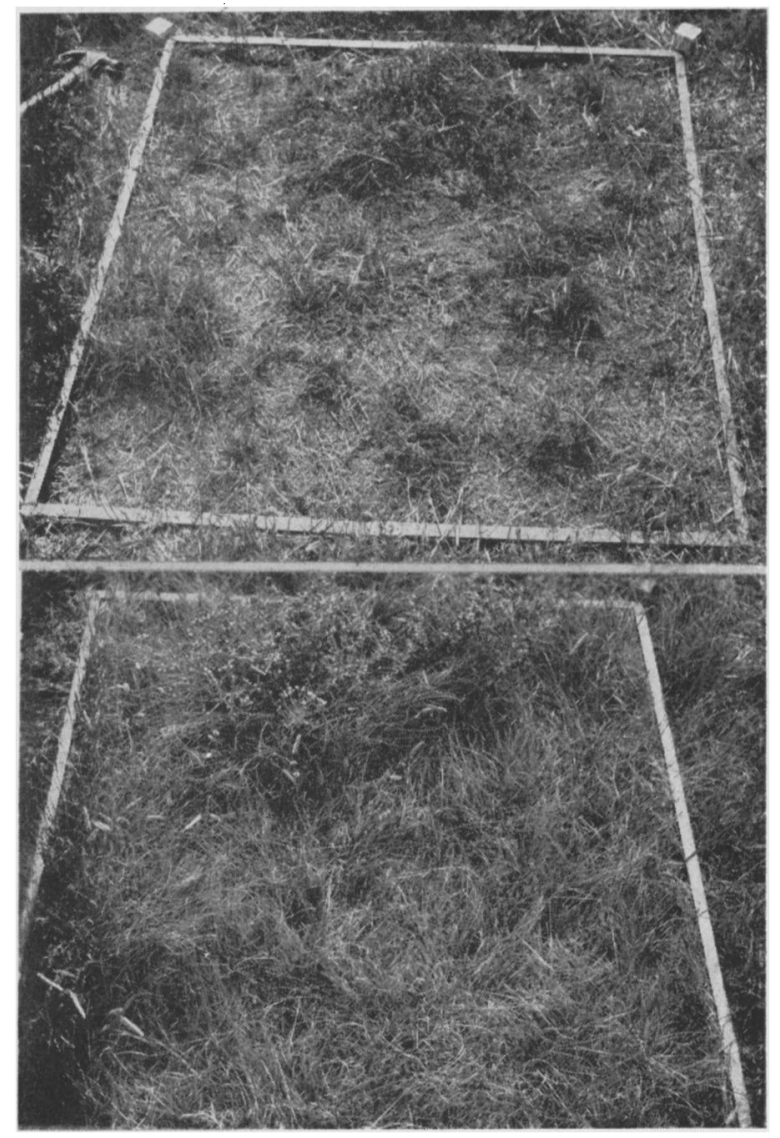

Fit. 14. Quadrat 1 of blue grama and buffalo grass, (upper) in autumn of 1940, when the basal cover was about 15 percent. (Lower) View in September, 1942, when the basal cover had increased to 61 percent. Two years later it was 95 percent. 
area; witchgrass obscured many of the scattered bunches of other grasses. The short grasses had replaced most coarse annual weeds and over much of the prairie the short grass mats were continuous. But side-oats grama was also widely spread and held the rank of the most abundant taller grass.

\section{THE RECORD FROM QUADRATS}

After thousands of years of adjustment and readjustment of the species of this mixed prairie to the vicissitudes of climate and the bright prospects for a new cover of short grasses, it had abruptly reached the end of its life-span. In 1945 the land was broken by plowing. A brief record of its last 5 years, however, was obtained by a series of permanent meter quadrats which were installed in 1940 . These had been placed at random along four lines extending parallel throughout its width. They were first charted with a pantograph in the fall of 1940 when the population of perennial plants was at low ebb. Eleven of the quadrats occurred in places where short grasses were dominant (Table 2). The slow but steady gain of blue grama from 8.8 to 25.2 percent during 4 years was surpassed by the spread of buffalo grass. From a cover of 4 percent in 1940 it increased to 45.5 by 1944 . A few other perennial

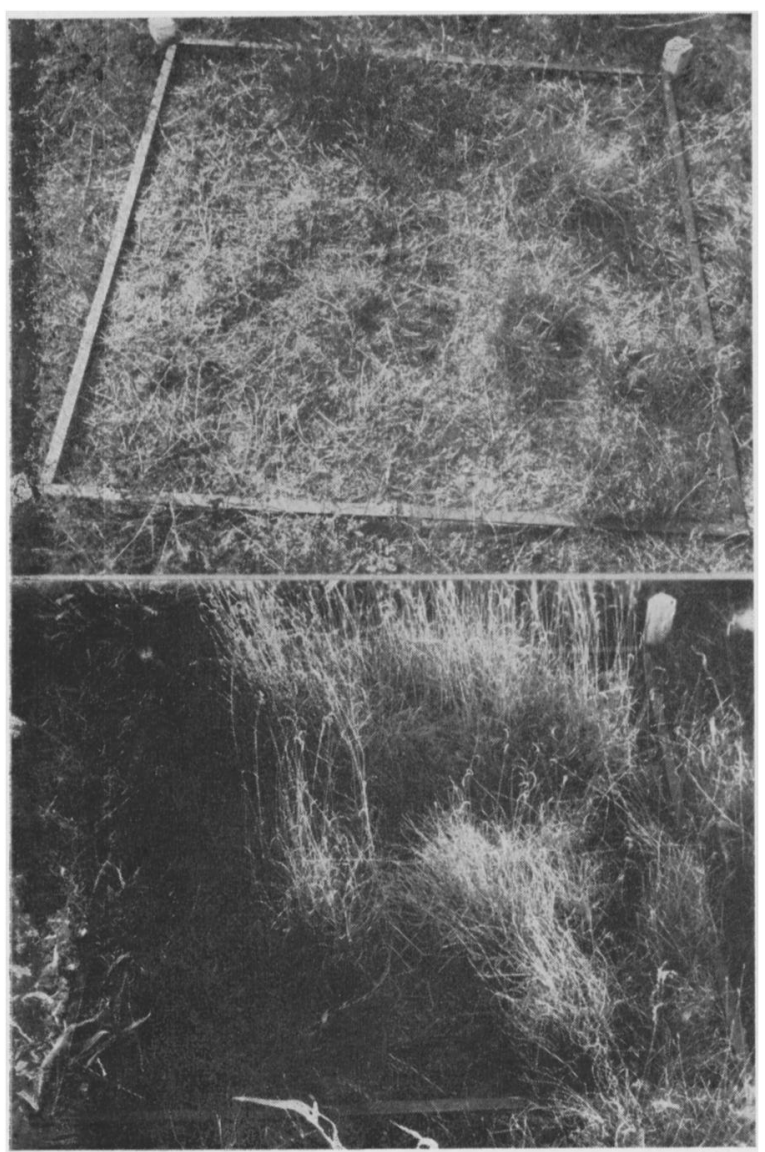

Fig. 15. Quadrat 14: (upper) in 1940 when the basal cover of blue grama was only 13 percent. This increased in a single year (lower) to 21.6 percent. grasses occurred in small amounts; native forbs and weeds were not charted (Fig. 14).

In quadrats dominated by blue grama, in the absence of buffalo grass, the increase was only from 8.8 to 15.1 percent (Table 2). This was about doubling the original basal cover in the period in which buffalo grass increased 11 fold (Fig. 15). In five quadrats where the original area of side-oats grama was 1.7 percent, the basal cover of this species increased gradually to 31.5 percent (Fig. 16). That of sand dropseed decreased. In other quadrats where the four chief grasses were intermixed, buffalo grass increased most rapidly, from 1.2 to 34.6 percent, sideoats grama was second ( 0.8 to 13.5 percent), but blue grama and sand dropseed did more poorly (Table 2 and Fig. 17).

The total basal cover of perennial grasses in each quadrat of the several groups is shown in Table 3 . In the blue grama-buffalo grass cover there was a good increase in each quadrat every year. The actual basal area by years was $13,36,48,61$, and 72 percent. Increase in the quadrats of blue grama was not so great nor so uniform. Gain in basal cover of side-oats grama was not always uniform year by year, but the average basal area increased steadily

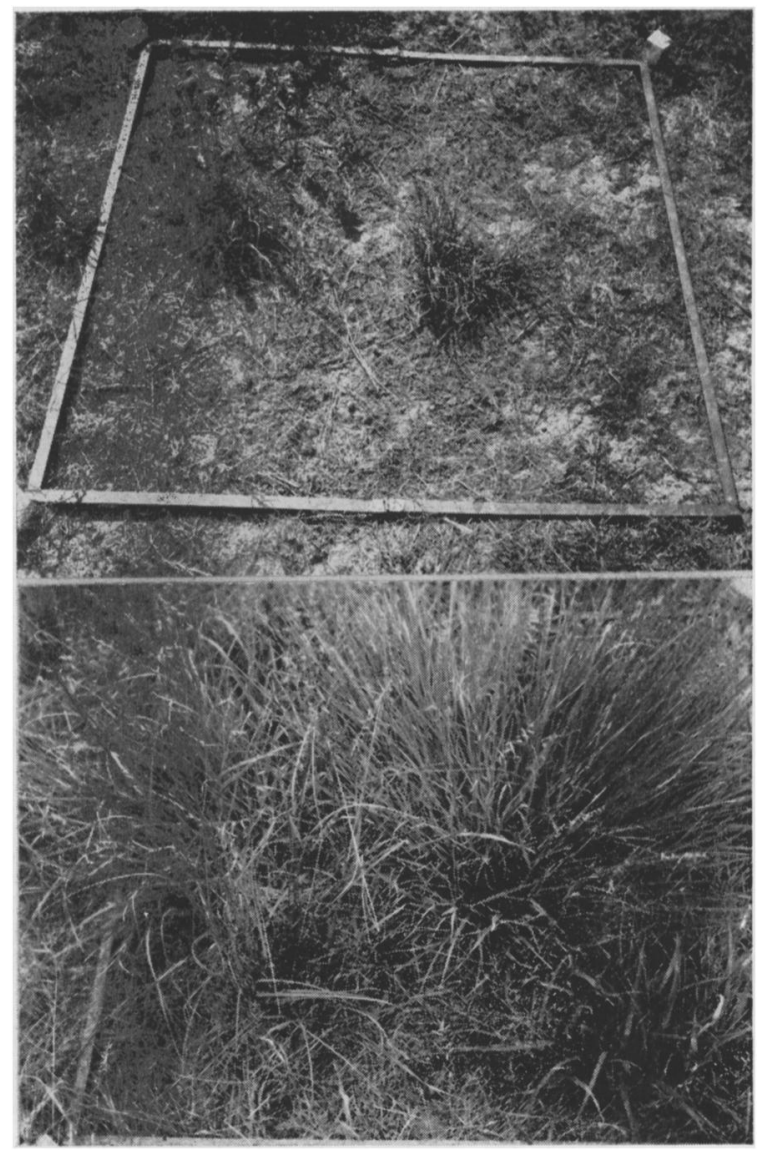

Fig. 16. Quadrat 7 of side-oats grama: (upper) in 1940 , with a basal cover of only 2.5 percent; (lower) in 1942 after two years very favorable for growth. Basal cover is about 14 percent. 
TABLE 2. Average basal area of the several species of grasses during each autumn, 1940 to 1944, as measured by the pantograph-chart quadrat.

\begin{tabular}{|c|c|c|c|c|c|}
\hline Species & 1940 & 1941 & 1942 & 1943 & 1944 \\
\hline & \multicolumn{5}{|c|}{ Blof Grama and Buffalo Grass } \\
\hline Boutelous gracilis. & 8.8 & 16.5 & 20.9 & 21.8 & 25.2 \\
\hline Buchloe dactyloides. . & 4.0 & 18.9 & 25.9 & 37.8 & 45.5 \\
\hline Sporobolus cryptandrus. . & 0.0 & 0.2 & 1.1 & 1.0 & 0.4 \\
\hline \multirow[t]{2}{*}{ Bouteloua curtipendula ........ } & 0.0 & 0.0 & 0.2 & 0.3 & 0.4 \\
\hline & \multicolumn{5}{|c|}{ Bloe Graya } \\
\hline Boutelous gracilis. & 8.8 & 15.5 & 16.5 & 13.0 & 15.1 \\
\hline \multirow{2}{*}{ Boutelous curtipendula ........ } & 0.0 & 0.8 & 0.9 & 1.5 & 1.7 \\
\hline & \multicolumn{5}{|c|}{ Side-0atb Graya } \\
\hline Boutelous curtire idula ........ & 1.7 & 9.3 & 14.9 & 19.7 & 31.5 \\
\hline \multirow[t]{2}{*}{ Sporobolus eryrtandrus......... } & 0.0 & 1.1 & 1.6 & 0.6 & 0.1 \\
\hline & \multicolumn{5}{|c|}{ Mixed Grasses } \\
\hline Boutelous gracilis. . & 3.7 & 8.0 & 6.6 & 6.9 & 7.8 \\
\hline Buchloe dactyloides...... & 1.2 & 13.5 & 24.1 & 24.5 & 34.6 \\
\hline Bouteloua curtipendula... & 0.8 & 4.4 & 5.1 & 7.3 & 13.5 \\
\hline Sporobolus cryptandrus........ & 0.0 & 3.2 & 4.0 & 5.5 & 3.5 \\
\hline
\end{tabular}

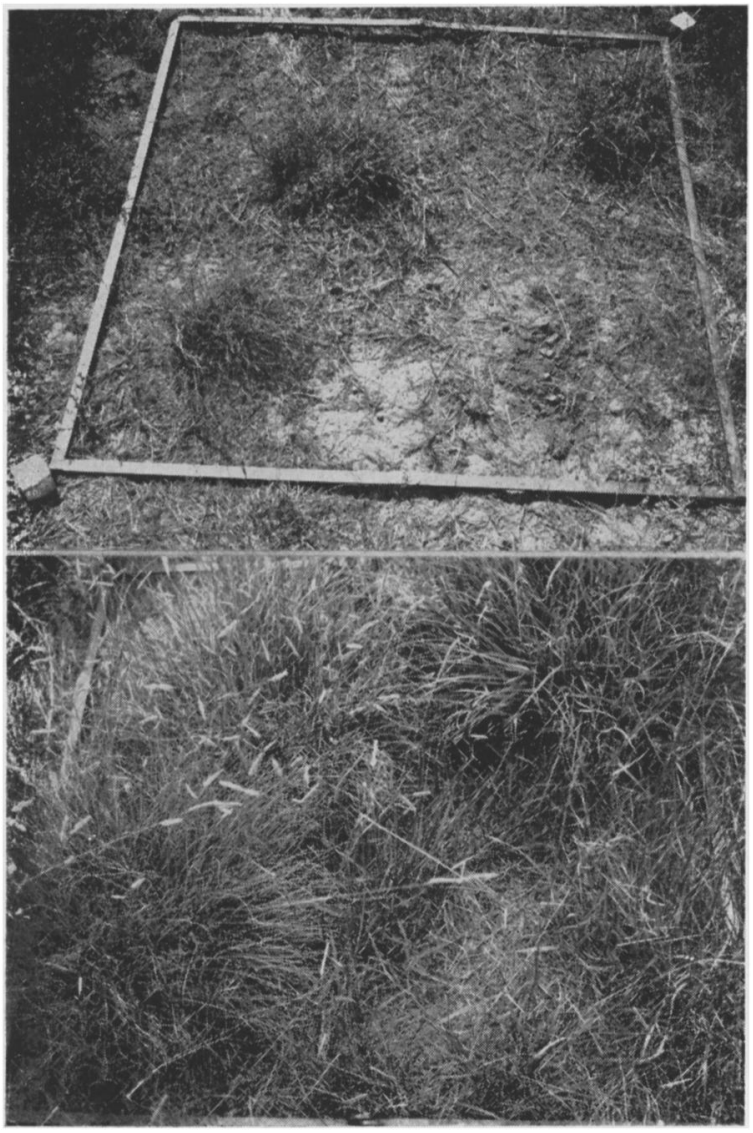

Fia. 17. Quadrat 2 of blue grama and side-oats grama. From a basal cover of 5.8 percent in 1940 (upper) it increased to 22.5 in 1942 (lower), and was 36 percent in 1944 .
TABLE 3. Total basal area of perennial grasses in each of 20 quadrats each year and average basal cover in each type of quadrat.

\begin{tabular}{|c|c|c|c|c|c|}
\hline Quadrat & 1940 & 1941 & 1942 & 1943 & 1944 \\
\hline & \multicolumn{5}{|c|}{ Blue Graya and Bufralo Grass } \\
\hline $1 \ldots \ldots \ldots \ldots \ldots$ & 14.7 & 48.1 & 61.4 & 95.3 & 94.6 \\
\hline $3 \ldots \ldots \ldots \ldots \ldots$ & 12.5 & 34.4 & 44.7 & 50.5 & 64.2 \\
\hline $5 \ldots \ldots \ldots \ldots \ldots$ & 14.2 & 28.0 & 46.6 & 58.5 & 63.4 \\
\hline $6 \ldots \ldots \ldots \ldots \ldots$ & 9.5 & 39.1 & 76.0 & 87.0 & 94.2 \\
\hline $8 \ldots \ldots \ldots \ldots$ & 5.2 & 45.8 & 54.0 & 71.5 & 86.1 \\
\hline $9 \ldots \ldots \ldots \ldots \ldots$ & 19.5 & 46.7 & 47.5 & 87.8 & 95.5 \\
\hline $10 \ldots \ldots \ldots \ldots \ldots$ & 14.9 & 34.0 & 45.9 & 46.0 & 86.8 \\
\hline $11 \ldots \ldots \ldots \ldots \ldots$ & 14.7 & 32.5 & 40.0 & 45.2 & 35.7 \\
\hline $16 \ldots \ldots \ldots \ldots \ldots$ & 8.4 & 19.8 & 32.2 & 38.7 & 52.0 \\
\hline $18 \ldots \ldots \ldots \ldots \ldots$ & 5.1 & 32.3 & 39.9 & 42.2 & 58.7 \\
\hline $20 \ldots \ldots \ldots \ldots \ldots, \ldots$ & 22.3 & 32.6 & 42.9 & 45.9 & 55.9 \\
\hline \multirow[t]{2}{*}{ Average...... } & 12.8 & 35.8 & 48.3 & 60.8 & 71.6 \\
\hline & \multicolumn{5}{|c|}{ Blue Grama } \\
\hline 4. & 4.5 & 10.9 & 11.7 & 13.6 & 6.5 \\
\hline $14 \ldots \ldots \ldots \ldots \ldots \ldots$ & 13.0 & 21.6 & 23.9 & 17.0 & 27.0 \\
\hline \multirow[t]{2}{*}{ Average...... } & 8.8 & 16.3 & 17.8 & 15.3 & 16.8 \\
\hline & \multicolumn{5}{|c|}{ Side-oats Grama } \\
\hline $7 \ldots \ldots \ldots \ldots \ldots$ & 2.5 & 8.8 & 14.1 & 20.7 & 29.7 \\
\hline $12 \ldots \ldots \ldots \ldots \ldots \ldots$ & 1.4 & 10.8 & 14.9 & 13.3 & 38.7 \\
\hline $13 \ldots \ldots \ldots \ldots \ldots$ & 1.2 & 16.6 & 25.2 & 31.3 & 41.4 \\
\hline $17 \ldots \ldots \ldots \ldots \ldots$ & 0.7 & 11.0 & 21.2 & 41.5 & 51.1 \\
\hline $19 \ldots \ldots \ldots \ldots \ldots$ & 2.7 & 9.5 & 15.8 & 2.4 & 4.2 \\
\hline \multirow[t]{2}{*}{ Average....... } & 1.7 & 11.3 & 18.2 & 21.8 & 33.0 \\
\hline & \multicolumn{5}{|c|}{ Mixed Grasares } \\
\hline $2 .$. & 5.8 & 21.5 & 22.5 & 31.3 & 35.9 \\
\hline $15 \ldots$ & 5.5 & 36.6 & 57.0 & 56.8 & 82.8 \\
\hline Average...... & 5.7 & 29.1 & 39.8 & 44.1 & 39.4 \\
\hline
\end{tabular}

and fairly rapidly from 1.7 to 33.0 percent cover. In the quadrats of mixed grasses, the basal area increased regularly to about ten times the cover in 1940.

The changes in plant yield from the drought years of 1939 and 1940 to the very wet one in 1941 are given in Table 4.

Increase in production of short grasses and mid grasses in one year was nearly ten-fold. Dry weight of forbs increased four-fold and weeds in about the same amount.

A study of the manner and rate of change in the composition of vegetation after the soil is once occupied by perennial grasses has been found to be very slow. The writers are therefore led to believe that if this prairie had not been broken but remained

TARLE 4. Grams of vegetation produced each of several years in 20 meter quadrats in the prairie at Phillipsburg, 1939 to 1941 .

\begin{tabular}{c|c|c|c|c|c}
\hline \hline Year & Short grass & Mid grass & Forbs & Weeds & Total \\
\hline $1939 \ldots \ldots \ldots \ldots$ & 682 & 844 & $\ldots$ & 2,152 & 3,678 \\
$1940 \ldots \ldots \ldots \ldots$ & 272 & 32 & 139 & 1,965 & 2,408 \\
$1941 \ldots \ldots \ldots \ldots$ & 2,113 & 329 & 571 & 7,572 & 10,585 \\
\hline
\end{tabular}


ungrazed, probably many years would have been required for the reduction of the short grasses to their former abundance in a normal mixed prairie cover.

\section{SUMMARY}

The history of a typical area of mixed prairie near Phillipsburg in north-central Kansas is recorded. Selected in 1920 as representative of the less xeric type of mixed prairie, drought and dust had reduced it over much of its area to a disclimax of buffalo grass (Buchloe dactyloides) and blue grama (Bouteloua gracilis) before it was broken in 1945 .

The nature of the original vegetation, the degree to which it was damaged by early severe drought, and its vicissitudes during the seven years of drought were studied by one or two examinations yearly. These examinations were supplemented near the end of the drought by annual measurements of basal area in 20 widely distributed meter quadrats.

The fertile, mellow, very fine sandy-loam loess soil absorbs water readily and has a high water-holding capacity. But even during years with normal precipitation, the vegetation was often subjected to moderate soil drought and during later years soil water was often not arailable at any depth to 5 feet for many days.

The mid grasses, little bluestem (Andropogon scoparius), side-oats grama (Bouteloua curtipendula), and western wheat grass (Agropyron smithii), together with taller ones-big bluestem (Andropogon furcatus), Indian grass (Snighastrum nutans), and nodding wild rye (Elymus canadensis)-alternated with blue grama and buffalo grass or formed an open laver above them. About 50 species of forbs, many of which formed extensive societies, were found.

Great damage was done by a single year of drought and dust burial in 1933. All plants suffered heavy losses; there was no living little bluestem and about half of the big bluestem had died. The understory of several low-growing grasses and forbs had completely disappeared. Although blue grama and buffalo grass had lost heavily, they alone recovered rapidly with spring rains. Only about 15 of the spccies of forbs remained; most of these were very deeply rooted or possessed other underground storage organs. The spring rains had promoted the development of a host of annual weeds, which occurred throughout but especially where a layer of dust 2.5 inehes or more in thickness had destroyed practically all of the native vegetation.

Intense drought alternating with periods of rainfall sufficient to revive the vegetation or even promote vigorous growth characterized a period of 5 years. The net result was a gradual decrease in tall and most mid grasses and less xeric forbs, offset by an increase in short grasses and side-oats grama. A population of annual weeds, although often greatly dwarfed, was characteristic.

A period of extreme drought, including the summer and fall of 1939 and the year 1940, followed. In the spring of 1940 only a little vegetation of any kind was left alive. Chief perennials were buffalo grass and blue grama. In fact, seedlings and new tufts were so plentiful that it seemed that short grasses might dominate the whole prairie. Conversely, nearly all of the mid and tall grasses had died or were dormant. Side-oats grama had apparently suffered a total loss. Native forbs were reduced to remnants of 11 species.

Heavy rainfall, beginning in 1941, followed the dry years. Conditions were very favorable to growth, but except for the short grasses there was little native vegetation to profit from the changed environment, and the supply of seed was at a low ebb. Moreover, development of short grasses was hindered by a rank growth of little barley (Hordeum pusillum) which grew tall and thickly. By midsummer the prairie had the aspect of a short grass disclimax, except for alternes consisting of about 20 annual weeds, and, in places, revived side-oats grama. Other perennial grasses were few.

The vear 1942 marked the continued spreading of the short grasses, and the consolidation of a formerly open cover. An average gain from 13 percent (1940) to 48 percent was recorded in 11 meter quadrats and much greater gains were common. The average basal cover was about 50 percent and the foliage cover was 80 to 100 . Blue grama still slightly exceeded buffalo grass in abundance. This carpet of short grass was 6 to 8 inches thick. The scattered relict stands of side-oats grama were being heavily invaded by buffalo grass which threatened to replace them.

During the next two years buffalo grass especially spread very rapidly and greatly exceeded blue grama in amount. Quadrats gave an average basal cover of more than 70 percent of short grasses. Usually they were so tall and dense that the soil was completely concealed. But elsewhere there were interspaces where annual weerls, mostly horseweed (Leptilon canadense), grew to 3 or 4 feet in height. Little barley and most low-growing weeds had nearly disappeared. Mid and tall grasses were nowhere abundant, although remnants of many could be found.

Thus, drought and dust unaided by grazing had reduced a sample area of mixed prairie centuries old to a disclimax of short grasses. Breaking the sod in 1945 ended the study abruptly. 


\section{LITERATURE CITED}

Albertson, F. W., \& J. E. Weaver. 1942. History of the native vegetation of western Kansas during seven years of continuous drought. Ecol. Monog. 12: 23-51.

Clements, F. E., \& J. E. Weaver. 1924. Experimental vegetation. Carnegie Inst. Wash. Pub. 355.

Shively, S. B., \& J. E. Weaver. 1939. Amount of underground plant materials in different grassland climates. Univ. Neb. Cons. and Surv. Div. Bul. 21.

Weaver, J. E. 1924. Plant production as a measure of environment. Jour. Ecology 12: 205-237.

1943. Replacement of true prairie by mixed prairie in eastern Nebraska and Kansas. Ecology 24: 421-434.
Weaver, J. E., \& F. W. Albertson. 1940. Deterioration of midwestern ranges. Ecology 21 : 216-236.

1943. Resurvey of grasses, forbs, and underground plant parts at the end of the great drought. Ecol. Monog. 13: 63-117.

1944. Nature and degree of recovery of grassland from the great drought of 1933 to 1940 . Ecol. Monog. 14: $393-479$.

Weaver, J. E., \& R. W. Darland. 1944. Grassland patterns in 1940. Ecology 25: 202-215.

Weaver, J. E., \& I. M. Mueller. 1942. Role of seedlings in recovery of midwestern ranges from drought. Ecology 23: 275-294. 